\title{
A NOTE ON A THERMOKARST FEATURE ON THE NORTH SLOPE OF ALASKA
}

\author{
R.G.WEST, J.J.DONNER and T.KANKAINEN
}

WEST, R.G.; DONNER, J.J. and KANKAINEN, T. 1994. A note on a thermokarst feature on the North Slope of Alaska. Bull. Geol. Soc. Finland 66, Part I, 45-52.

A thermokarst depression with active thermal erosion on one margin and a drainage way to the Sagavanirktok River is described with the aid of a sketch plan and sections. The depression is surrounded by moist tundra with thermal contraction polygons and floored by wet tundra with extensive pools. It is drained by a partly sinuous flat-floored shallow valley with gentle margins. Three radiocarbon dates from a section of organic sediment at the margin of the depression, exposed by erosion, show that its accumulation extends back at least 7410 radiocarbon years. A pollen spectrum from the organic sediment at 5240a $\mathrm{BP}$ indicates the presence of moist tundra heath with dwarf shrubs. The feature is briefly discussed in relation to Pleistocene relict thermokarst.

Key words: thermokarst, organic residues, pollen analysis, absolute age, C-13, Holocene, Alaska.

R.G.West: Subdepartment of Quaternary Research, Department of Plant Sciences, University of Cambridge, Downing Street, Cambridge CB2 3EA, U.K.

J.J.Donner: Department of Geology, P.O. Box 11), FIN-00014, University of Helsinki, Finland.

T.Kankainen: Radiocarbon Laboratory, Geological Survey of Finland, FIN-02150 Espoo, Finland. 


\section{INTRODUCTION}

Thermokarst depressions may be an important category of Pleistocene periglacial phenomena, yet there are few accounts of present-day expressions of such thermokarst which might be useful to intepret past possible thermokarst activity. The following is a brief outline account of a thermokarst depression on the North Slope of Alaska, which may show features which are to be found in areas with Pleistocene thermokarst.

The depression is in the Arctic Foothills region of the North Slope of Alaska and was examined in July 1990. It lies between the Dalton Highway (Elliot Highway to Prudhoe Bay) and the gravel floodplain of the Sagavanirktok River, half-a-mile north of Dalton Highway Milepost 338 (UTM zone 6 GR 0427075800 ) (Fig. 1). The site is that of a thaw lake mentioned by Brown \& Krieg (1983, p.193), who refer to the lake as actively eroding into an ice-rich peaty bluff. Drift of the Middle
Pleistocene Sagavanirktok Glaciation underlies the area(Brown \& Krieg 1983). Levels were determined by hand level and distances by pacing.

\section{DESCRIPTION}

A sketch plan of the depression is shown in Fig.2. A number of small lakes occupy the depression, the walls of which are generally vegetated, except where active erosion is present, as at section $\mathrm{A}$, on the west side of the depression. The surrounding vegetation is of a type included in the moist tundra of Viereck \& Little (1986), but near the margin of the depression drier shrub tundra is present, associated with better drainage. High centre polygons are present in the surrounding area, and impinge on the depression as wedge forms thawed and collapsing. At point A, $370 \mathrm{~cm}$ of peat was present in a bluff under active erosion, with collapse of frozen clasts of peat into the adjacent lake. Here
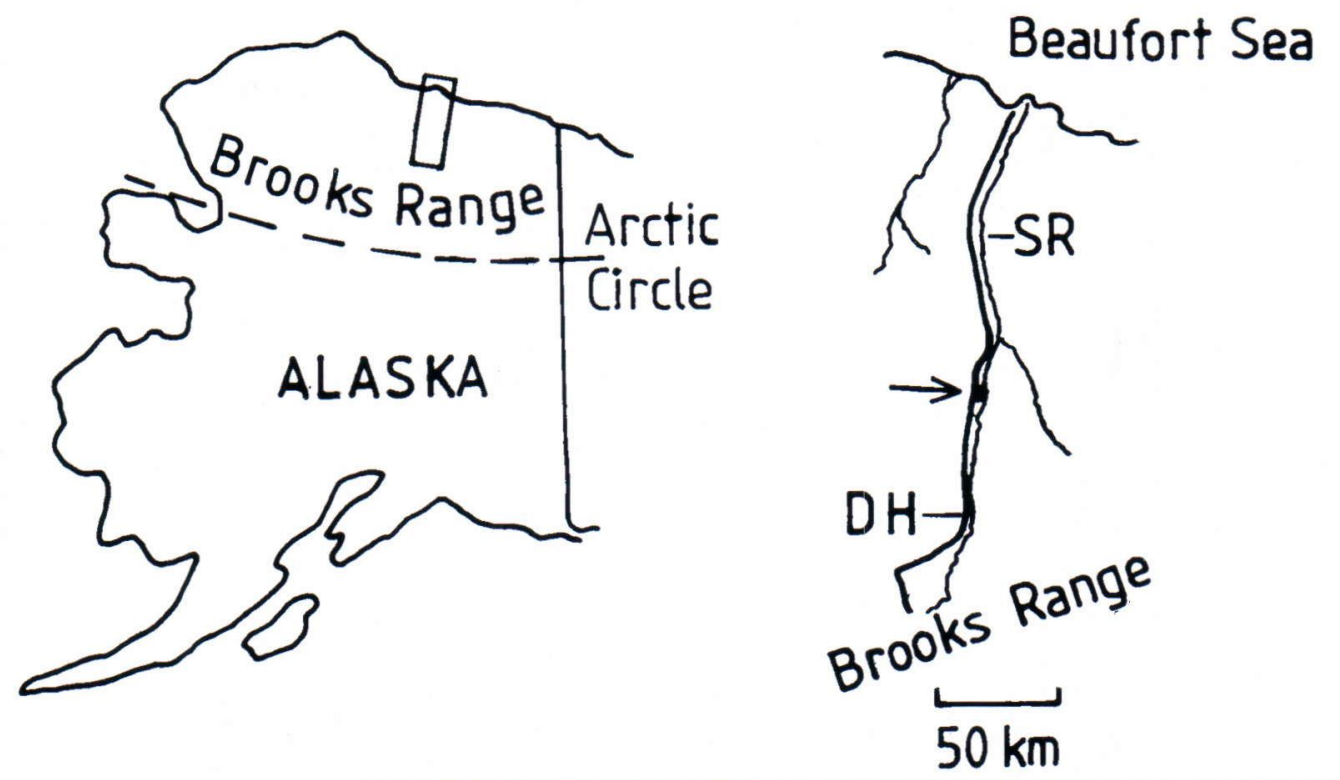

Fig. 1. Location of site. DH, Dalton Highway; SR, Sagavanirktok River. Arrow marks site. 


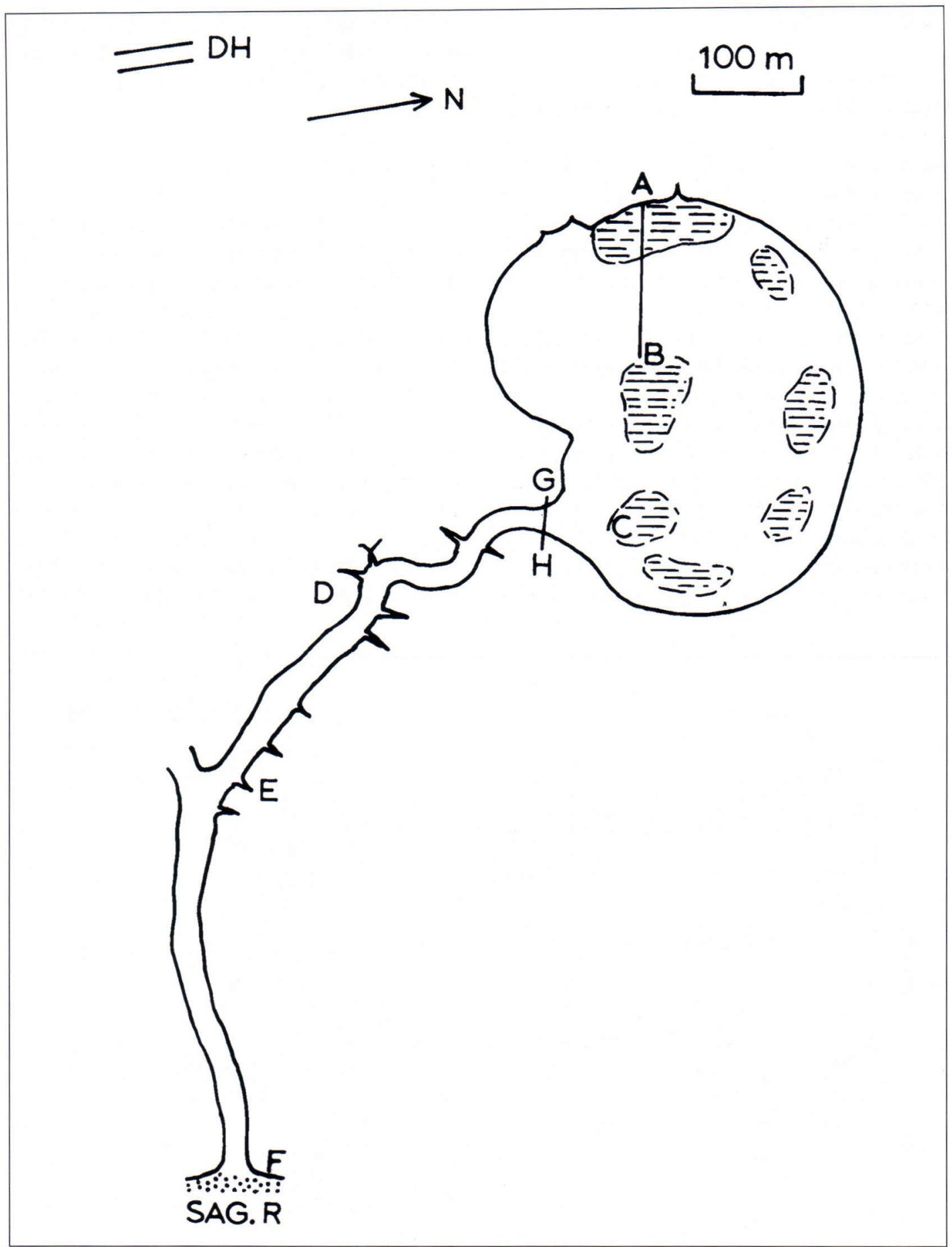

Fig. 2. Sketch plan of site, showing thaw lakes in the depression, drainage channel and positions(A-H) of section, profiles, and points on profiles. DH, Dalton Highway; SAG.R, Sagavanirktok River floodplain. 


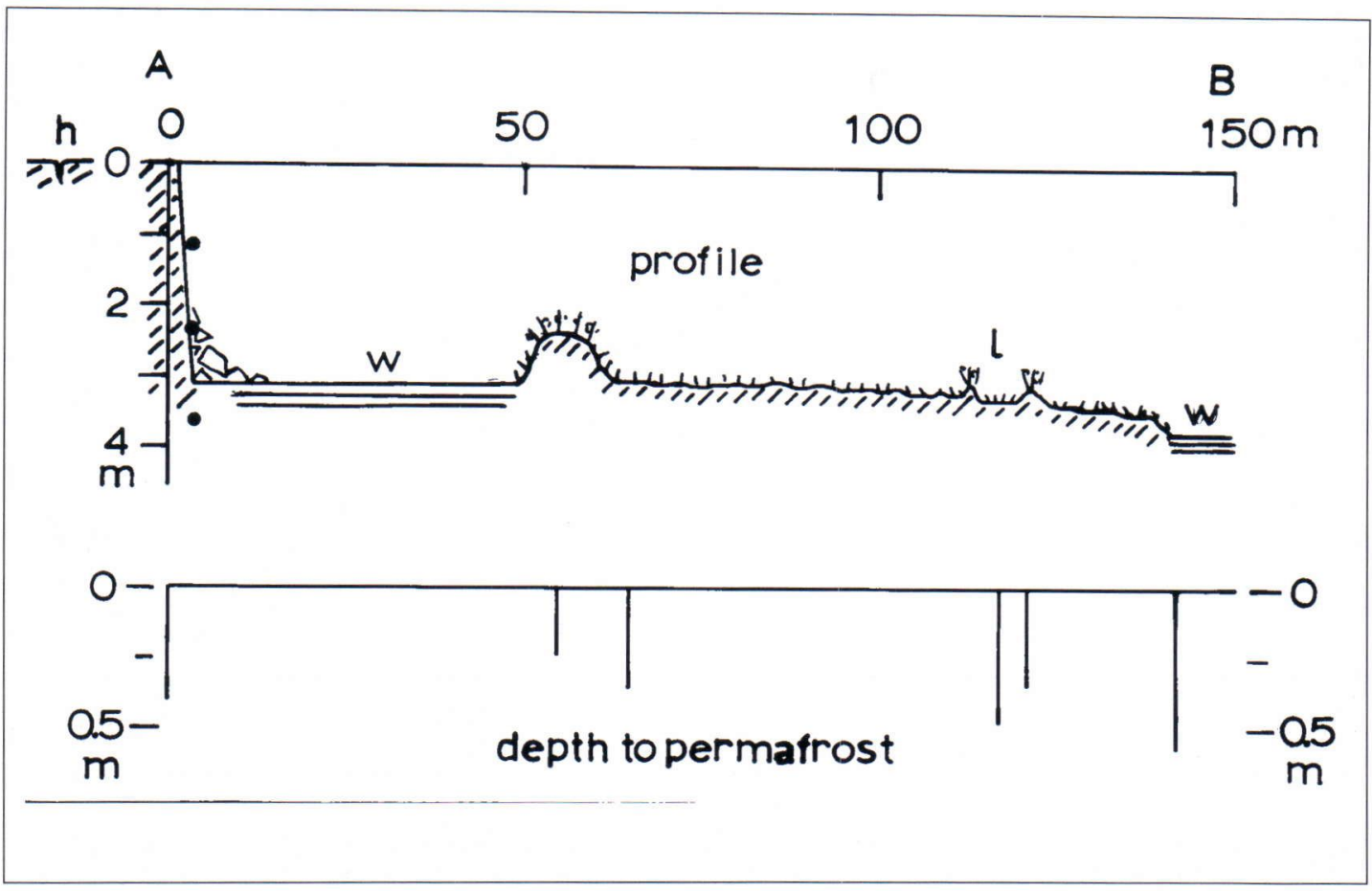

Fig. 3. Section at A, with profile A - B. h, high centre polygons; l, low centre polygons; w, water. The three dots in section $A$ are the positions of radiocarbon and pollen samples.

the active layer was $40 \mathrm{~cm}$ thick (see Fig. 3). Three samples of the organic sediment were taken for radiocarbon assay and pollen analysis at the points marked in the section by dots.

The depression contains several shallow pools, low centre polygons and, on better drained areas, shrub heath and high centre polygons (Fig. 2). The profile A to B (Fig. 3) shows surface heights and depth to permafrost surface (thickness of active layer), with shrub heath on the higher ridges and wet tundra in the lows. The depth to permafrost is greater under the wetter parts or the pools, as would be expected.

The depression is drained by a channel several metres wide, flat-bottomed, with slopes punctuated by wedge-shaped collapses resulting from melting of ice in contraction cracks which form polygons in the surrounding area. A sketch plan of the channel is shown in Fig.2, and Fig. 4 gives a long profile of the flat bottom of the channel. This is clearly seen in the cross profile $\mathrm{G}-\mathrm{H}$ in Fig. 5, near the head of the channel. The long profile starts at $\mathrm{C}$ at the margin of a pool. To point $\mathrm{D}$ the channel has a low gradient and is sinuous, probably a result of control of drainage by thawed wedges of the polygon system. Hopkins \& Kidd (1988) comment that "Thaw-back along an ice wedge is probably the most frequent proximal cause of thaw-lake drainage". Below D the channel is straighter and steeper. At E it is joined by a drainage channel from another depression to the south. Point F marks the outlet to the Sagavanirktok River gravel floodplain.

\section{RADIOCARBON DATES}

Table 1 gives the results of radiocarbon assays of three samples from section A, positions shown in 


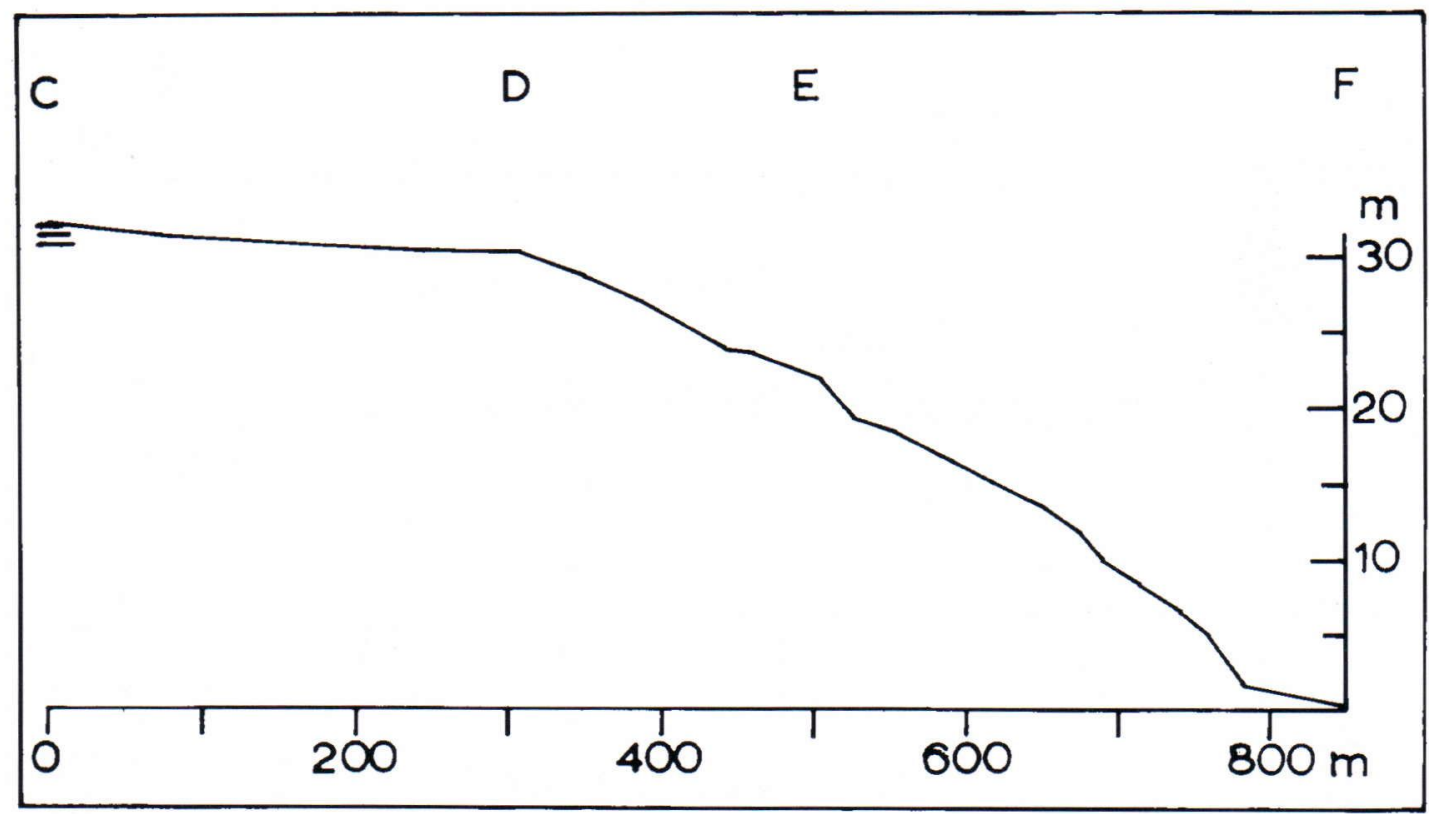

Fig. 4. Long profile of flat floor of drainage channel, C-F.D, change from sinuous to straighter course; $E$, confluence with a drainage channel from another depression; $F$, junction with Sagavanirktok River floodplain.

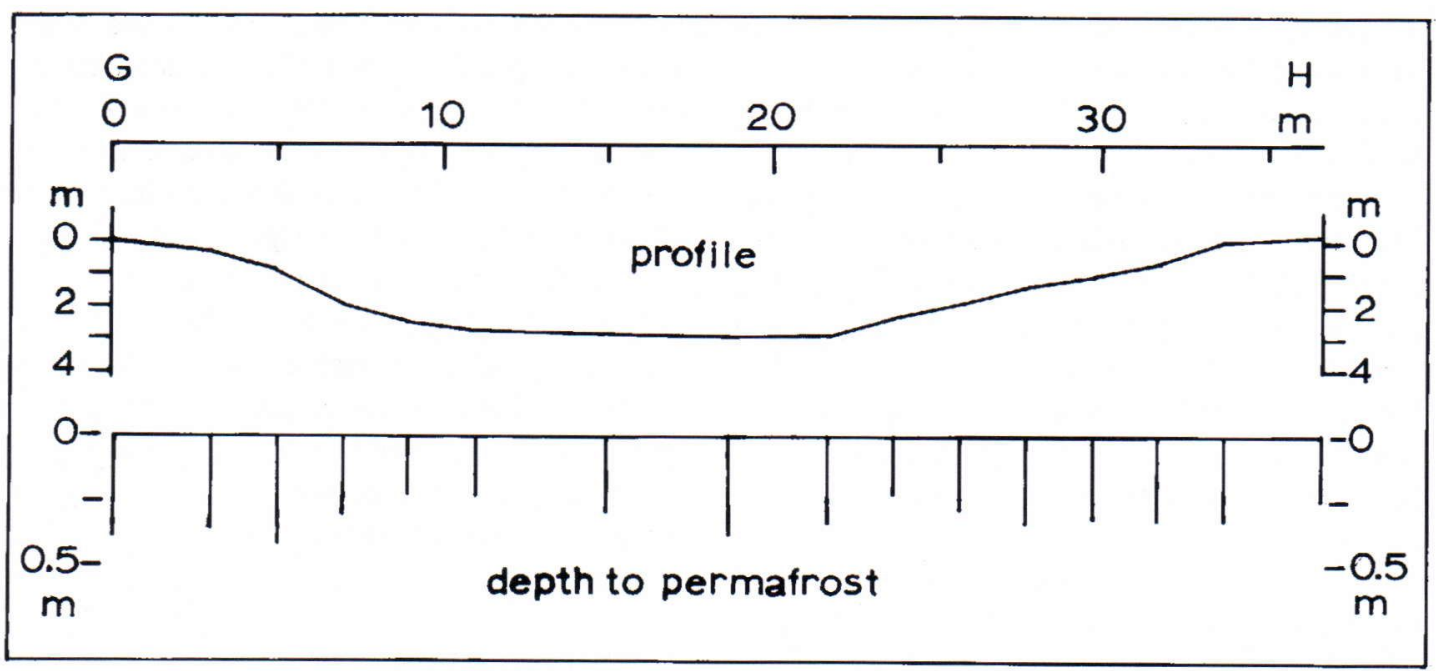

Fig. 5. Cross profile G-H near head of drainage channel. 
Table 1. Radiocarbon dates from section A.

\begin{tabular}{|c|c|c|c|c|}
\hline Depth & $\begin{array}{l}\text { Radiocarbon age } \\
\text { and } \partial^{13} \mathrm{C} \text { value }\end{array}$ & $\begin{array}{l}1 \sigma \text { cal. BP } \\
\text { age range }\end{array}$ & $\begin{array}{l}\text { Most probable } \\
\text { cal. BP age }\end{array}$ & $\begin{array}{l}\text { Sediment } \\
\text { growth rate }\end{array}$ \\
\hline $110-120 \mathrm{~cm}$ & $\begin{array}{l}\text { Su-1977 } 3730 \pm 40 \mathrm{BP} \\
\partial^{13} \mathrm{C}=-30.2 \mathrm{o} / \mathrm{oo}\end{array}$ & $4110-4000$ & 4055 & $0.028 \mathrm{~cm} / \mathrm{a}$ \\
\hline $2230-240 \mathrm{~cm}$ & $\begin{array}{l}\mathrm{Su}-19785240 \pm 40 \mathrm{BP} \\
\partial^{13} \mathrm{C}=-29.4 \mathrm{o} / \mathrm{oo}\end{array}$ & $6040-5950$ & 5980 & $0.062 \mathrm{~cm} / \mathrm{a}$ \\
\hline $360-370 \mathrm{~cm}$ & $\begin{array}{l}\text { Su-1979 } 7410 \pm 50 \mathrm{BP} \\
\partial^{13} \mathrm{C}=-28.4 \mathrm{o} / \mathrm{oo}\end{array}$ & $8200-8120$ & 8150 & $0.060 \mathrm{~cm} / \mathrm{a}$ \\
\hline
\end{tabular}

Fig. 3. The samples, each $10 \mathrm{~cm}$ thick, were cut from the cleaned section when the surface had thawed about $10-15 \mathrm{~cm}$ in a few days. The alkali-insoluble fraction was used for dating, after an acid-alkali-acid pretreatment. The dating technique involved proportional countingof $\mathrm{CO}_{2}$ and the application of pulse-shape discrimination as described by Mäntynen et al. (1987) and Äikää et al. (1992). Table 1 also gives $\partial^{13} \mathrm{C}$ values. The radiocarbon ages were converted to calendar years for calculation of sediment growth rates. The calibration was done with a computer programme devised by Stuiver \& Reimer (1993). The ages indicate that the growth rate slowed down some time after about $4000 \mathrm{BP}$, probably as a result of the drainage of the basin. This age may relate to the time of first enlargement and development of the depression.

\section{POLLEN ANALYSES}

Three samples from frozen organic sediment in section A, positions shown in Fig. 3, were prepared for analysis. Only the sample from $220-230 \mathrm{~cm}$ (radiocarbon age 5240 a BP), the middle of the three, contained pollen in sufficient quantity for a count. The topmost sample was very humified and contained few pollen grains (Betula, Picea, Ericales). The results from the middle sample are given in Table 2 . The sediment was largely slightly humified detritus herbosus of Troels-Smith (1955), and the pollen washing contained a leaf of Betula glandulosa/nana. This is reflected in the high pollen percentage of Betula. There are much lower percentages of Picea, Alnus and Salix. The former two are better represented in recent pollen rain in pool peat in the area (West et al. 1993). Heath pollen is better represented, with several moist tundra taxa, totalling $20 \%$ of the pollen. Remaining taxa showing a good representation are Eriophorum (9\%) and Rubus chamaemorus (4\%). The Cyperaceae values are very low compared with those found in limnic sediments in wet tundra.

The pollen spectrum indicates the local presence of the shrub heath aspect of moist tundra, with dwarf birch, Empetrum, Eriophorum, Polygonum bistorta and Rubus chamaemorus, much as is present today in the area, with accumulation of organic detritus in a wet area.

\section{DISCUSSION}

The presence of organic sediment at the margin of the depression shows accumulation of organic 
Table 2. Pollen analysis, section A, $235 \mathrm{~cm}$.

\begin{tabular}{|c|c|c|}
\hline & No. & $\begin{array}{l}\% \text { total } \\
\text { pollen }\end{array}$ \\
\hline Betula & 300 & 45 \\
\hline Picea & 24 & 4 \\
\hline Alnus & 46 & 7 \\
\hline Salix & 23 & 3 \\
\hline Ericales undiff. & 35 & 5 \\
\hline Empetrum & 61 & 9 \\
\hline Andromeda & 23 & 3 \\
\hline Arctostaphylos & 5 & 0.7 \\
\hline Vaccinium & 12 & 2 \\
\hline Ledum & 9 & 1 \\
\hline Poaceae & 2 & 0.3 \\
\hline Cyperaceae & 15 & 2 \\
\hline Eriophorum & 59 & 9 \\
\hline Juncus & 15 & 2 \\
\hline Artemisia & 4 & 0.6 \\
\hline \multicolumn{3}{|l|}{ Polygonum } \\
\hline bistorta type & 3 & 0.5 \\
\hline \multicolumn{3}{|l|}{ Rubus } \\
\hline chamaemorus & 24 & 4 \\
\hline Valeriana & 1 & 0.1 \\
\hline Equisetum & 8 & 1 \\
\hline Total pollen & 661 & \\
\hline
\end{tabular}

\section{REFERENCES}

Äikää, O., Mäntynen, P. \& Kankainen, T. 1987. High performance ${ }^{14} \mathrm{C}$ gas proportional counting system applying pulse-shape discrimination. Radiocarbon, 34, 414-419.

Billings,W.D. \& Peterson, K.M. 1980. Vegetational change and ice-wedge polygons through the thaw lake cycle in Arctic Alaska. Arctic and Alpine Research, 12, 413-432. sediment had been proceeding in the area for at least 7400 radiocarbon years before encroachment by the present expanding thermokarst depression. Possibly the sediment accumulated in an earlier thaw lake depression, giving an example of the thaw lake cycle well-known from thaw lakes on the coastal plain to the north (Britton 1957; Billings \& Peterson 1980; Rawlinson 1983).

A comment on pollen taphonomy in the area derives from thermal erosion producing large clasts of frozen organic sediment with a shrub heath pollen spectrum collapsing into a pool bordered by sedge communities. Mixing of pollen spectra originating from different sediments must result, a confusion which is likely to be encountered in the analysis of thaw lake sediments (see Hopkins \& Kidd 1988).

This description of the form of the depression and its drainage way may be of use in interpreting depressions with drainage ways found in areas affected by Pleistocene permafrost. Such depressions occur in the southern Fenland of Eastern England, with similar flat-bottomed shallow drainage channels (West 1991), and they may well be more widespread than is generally realised.

ACKNOWLEDGMENTS: The authors are indebted to M.E.Edwards and D.M.Hopkins for their invaluable help in arranging field work, to the University of Alaska at Fairbanks Department of Geology and Museum for the loan of equipment and support, to J. Kidd for field work assistance, to R.Andrew for the pollen analysis, to S.Boreham and J.Dye for technical assistance and to N.E.R.C. and The New Phytologist Trustfor grant support.

Britton,M.E. 1957. Vegetation of the Arctic Tundra. In Arctic Biology, ed. H.P.Hansen, pp. 22-61. Corvallis; Oregon State University Press.

Brown,J. \& Krieg,R.A. eds. 1983. Guidebook to permafrost and related features along the Elliot and Dalton Highways, Fox to Prudhoe Bay, Alaska. Guidebook 4, Fourth International Conference on Permafrost. Pp. 1-230. Fairbanks; University of Alaska.

Hopkins,D.M. \& Kidd, J.G.(1988). Thaw lake sediments 
and sedimentary environments. Permafrost, 5th International Conference (Trondheim 1988), Proceedings, 1, 790-795.

Mäntynen,P., Äikää,O., Kankainen,T. \& Kaihola,L. 1987. Application of pulse-rate discrimination to improve the precision of the carbon-14 gas proportional counting method. Applied Radiation Isotopes, 38, 869-873.

Rawlinson,S.E. ed. Guidebook to permafrost and related features, Prudhoe Bay, Alaska. Guidebook 5, Fourth International Conference on Permafrost. Pp. 1-177. Fairbanks; University of Alaska.

Stuiver, M. \& Reimer,P.J. 1993. Extended ${ }^{14} \mathrm{C}$ data base and revised calib $3.0{ }^{14} \mathrm{C}$ age calibration program.
Radiocarbon, 35, 215-230.

Troels-Smith,J. 1955. Characterisation of unconsolidated sediments. Danmarks Geologiske Unders $\emptyset$ gelse, IV Raekke, 3, No. 10, 1-73.

Viereck, L.A. \& Little,E.L. 1986. Alaska trees and shrubs. Agriculture Handbook, No.410, pp. 1-265, Forest Service, U.S. Department of Agriculture, Fairbanks; University of Alaska Press.

West,R.G. 1991. On the origin of Grunty Fen and other landforms in southern Fenland, Cambridgeshire. Geological Magazine, 128, 257-262.

West,R.G., Andrew,R. \& Pettit,M. 1993. Taphonomy of plant remains on floodplains of tundra rivers, present and Pleistocene. New Phytologist, 123, 203-221. 